\title{
OCCURRENCE OF TOXIGENIC FUNGI IN HERBAL DRUGS
}

\author{
Adriana Bugno $^{1 *}$; Adriana Aparecida Buzzo Almodovar ${ }^{1}$; Tatiana Caldas Pereira ${ }^{1}$; Terezinha de Jesus Andreoli Pinto ${ }^{2}$; \\ Myrna Sabino ${ }^{1}$
}

\author{
${ }^{1}$ Instituto Adolfo Lutz, São Paulo, SP, Brasil; ${ }^{2}$ Faculdade de Ciências Farmacêuticas, Universidade de São Paulo, \\ São Paulo, SP, Brasil
}

Submitted: June 02, 2005; Returned to authors for corrections: December 12, 2005; Approved: January 23, 2006

\begin{abstract}
The increase in the consumption of natural drugs have made their use a Public Health problem due to the possibility of access to products without adequate conditions of use. The concern with the quality of the natural products is due to the potential fungal contamination and the risk of the presence of mycotoxins. Ninety-one samples of medicinal plants were evaluated for the fungal contamination and the mycotoxigenic potential of Aspergillus and Penicillium isolated from the samples. Results indicated that predominant mycoflora was distributed in 10 genera. From these, $89.9 \%$ of the isolates corresponded to genera Aspergillus and Penicillium, which are extremely important from the mycotoxicological standpoint. $21.97 \%$ of the Aspergillus and Penicillium isolates proved to have the ability for producing aflatoxins (42.9\%), ochratoxin A (22.4\%) and citrinine (34.7\%). The presence of toxigenic moulds represents a potential risk of mycotoxin contamination and considering the worldwide increased use of herbal products as alternative medicines, it is necessary setting standards for toxigenic moulds in crude herbal drugs in order to reduce the risks for consumers' health.
\end{abstract}

Key words: herbal drugs, medicinal plants, toxigenic moulds, mycotoxins

\section{INTRODUCTION}

Plants have been used in the prevention, treatment and cure of disorders and diseases since ancient times. In spite of their origin, natural drugs should not be viewed as simple tools of folk medicine since they are a class of pharmaceutical products and should meet the requirements of quality, safety and efficacy $(3,4)$.

The advancements of synthetic medicine overshadowed the traditional herbal medicine for over 50 years. However, in the last years there was a progressive increase in the demand of herbs and preparations of botanical origin as alternative or complementary medicine due to economical, social and cultural factors $(3,4)$. The increasing popularity of natural drugs made their use a Public Health problem due to the lack of effective surveillance of the use, efficacy, toxicity and quality of these natural products. The premise that traditional use of these medicinal products for generations establishes their safety does not necessarily attest to their safety and efficacy. Indeed, the adverse effects of long-term herbal use, adulteration with toxic compounds and contamination by pathogenic microbials or natural toxins like mycotoxins have been reported for herbal products and medicinal plants $(1,2,7-11,13,16-22,25)$.

The concern over quality of these products is mainly due to their potential contamination, considering their natural origin. Practices used in harvesting, handling, storage, production and distribution make medicinal plants subject to contamination by various fungi, which may be responsible for spoilage and production of mycotoxins $(1,11,13,25)$. Fungi of the genera Aspergillus and Penicillium, largely distributed in the Brazilian ecosystem, are known to contain strains that produce mycotoxins.

In spite of the extensive research on the occurrence of mycotoxins in foods, there are some reports available on the

*Corresponding Author. Mailing address: Instituto Adolfo Lutz, Av. Dr. Arnaldo, 355, Cerqueira Cesar. 01246-902, São Paulo, SP, Brasil. Tel.: (+5511) 3068-2863, Fax: (+5511) 3068-2926. E-mail: adrbugno@ial.sp.gov.br 
incidence of toxigenic mycoflora and mycotoxins in medicinal plants and phytotherapic compounds worldwide (1,2,5,7-11, 13,16-22,25).

Considering the little information on the toxigenic moulds in medicinal plants in Brazil, the objectives of the present study were to evaluate the predominant mycoflora and the extent of fungal contamination in medicinal plants and investigate the strains of fungi isolated for their ability to produce mycotoxins, such as aflatoxins, ochratoxin A and citrinine. The data obtained will be value as an indicator of the potencial for mycotoxin production.

\section{MATERIALS AND METHODS}

\section{Sampling}

Ninety-one samples of medicinal herbs, composed by 65 different plant species, were evaluated in order to assess the predominant mycoflora and the extent of fungal contamination. The products were chosen on the basis of their commercial availability and popularity of use and were obtained from four different suppliers in São Paulo (Table 1).

\section{Evaluation of fungal contamination}

Ten gram of each sample were mechanically homogenized in $90.0 \mathrm{~mL}$ of buffered peptone water (MERCK) for 2 minutes. Tenfold serial dilutions were performed up to $10^{-6}$, in buffered peptone water (MERCK). Enumeration of fungi was performed by pour plating method (26), using Sabouraud Agar with chloramphenicol (DIFCO). Plates were incubated upside down at $26 \pm 1^{\circ} \mathrm{C}$ for 7 days. After incubation, the fungal colonies were counted, recorded and the number of colony-forming units (CFU) per gram were calculated.

Mould colonies representative of all morphologically different types present were inoculated onto Potato Dextrose Agar (MERCK) and incubated at $26 \pm 1^{\circ} \mathrm{C}$ for 10 days. Identification was performed by cultural and morphological characteristics and followed the taxonomic schemes of Raper and Fennel (15) for the genus Aspergillus and Pitt (14) for the genus Penicillium.

\section{Evaluation of toxigenic potential}

All 223 isolates of Aspergillus and Penicillium were screened for the ability to produce aflatoxins and ochratoxin A by the inoculation in Coconut Agar Medium $(6,12)$ at $\mathrm{pH} 7.0 \pm$ 0.1 , and the ability to produce citrinine by the inoculation in Coconut Agar Medium $(6,12)$ at $\mathrm{pH} 5.0 \pm 0.1$. All plates were incubated at $26 \pm 1^{\circ} \mathrm{C}$, for 10 days. After the incubation, the colony and the culture medium around it were transferred to glass flasks, weighted and macerated in chloroform (MERCK), at a ratio of $3 \mathrm{~mL} / \mathrm{g}$. The macerate produced was filtered in filter paper, and the filtrate obtained was evaporated to dryness on a water bath. Mycotoxins were qualitatively detected by thin-
Table 1. Herbal drugs analyzed.

\begin{tabular}{|c|c|}
\hline Common name & Scientific name \\
\hline Absinthe & Artemisia absinthium \\
\hline Abutua & Chondrodendron tomentosum \\
\hline Agoniada & Plumeria lancifolia \\
\hline Altea & Althaea officinalis \\
\hline Angélica & Angelica archangela \\
\hline Anise & Pimpinella anisum \\
\hline Artichoke $^{(b)}$ & Cynara scolymus \\
\hline Baccharis $^{(a)}$ & Baccharis gaudichaudiana \\
\hline Boldo $^{(a)}$ & Peumus boldus \\
\hline Burdock & Arctium lappa \\
\hline Caaroba & Jacarandá caroba \\
\hline Cáscara sagrada ${ }^{(\mathrm{b})}$ & Rhamnus purshiana \\
\hline Catuaba & Trichilia catigua \\
\hline Centaury & Centaurium erythraea \\
\hline Chá-de-bugre & Cordia ecalculata \\
\hline Chamomile $^{(\mathrm{b})}$ & Matricaria recutita \\
\hline Chapéu-de-couro ${ }^{(\mathrm{a})}$ & Echinodorus macrophyllus \\
\hline Chinese rhubarb & Rheum palmatum \\
\hline Cipó-prata & Banistera argyrophylla \\
\hline Colomba & Jateorhiza palmata \\
\hline Condurango & Marsedenia condurango \\
\hline Congorosa & Maytenus ilicifolia \\
\hline Corn silk & Zea mays \\
\hline Escamônea & Convolvulus scammonia \\
\hline European Elder ${ }^{(b)}$ & Sambucus nigra \\
\hline Fennel & Foeniculum vulgare \\
\hline Frangula & Rhamnus frangula \\
\hline Fucus $^{(\mathrm{b})}$ & Fucus vesiculosus \\
\hline Germander & Teucrium chamaedrys \\
\hline $\operatorname{Ginkgo}^{(\mathrm{c})}$ & Ginkgo biloba \\
\hline Green tea & Camelia sinensis \\
\hline Guaraná(b) $^{(b)}$ & Paullinia cupana \\
\hline Holy thistle & Carduus benedictus \\
\hline Horse chesnut & Aesculus hippocastanum \\
\hline Horsetail $^{(\mathrm{a})}$ & Equisetum arvense \\
\hline Hyssop & Hyssopus officinalis \\
\hline Ipê-roxo & Tabebuia avellanedae \\
\hline Jaborandi & Pilocarpus microphylus \\
\hline Jalap ${ }^{(a)}$ & Phytolacca americana \\
\hline Jasmime & Jasminum officinalis \\
\hline Jurubeba & Solanum paniculatum \\
\hline Krameria & Krameria triandra \\
\hline Lavander $^{\text {(a) }}$ & Lavandula officinalis \\
\hline Lemongrass & Cymbopogon citratus \\
\hline Linden & Tília cordata \\
\hline Macela & Achyrocline satureoides \\
\hline Malva & Malva sylvestris \\
\hline Melissa $^{(a)}$ & Melissa officinalis \\
\hline Muirapuama & Ptychopetalum olacoides \\
\hline
\end{tabular}




\begin{tabular}{ll} 
Mullein & Verbascum densiflorum \\
Oak & Quecus robur \\
Paraguay tea & Illex paraguariensis \\
Pfaffia & Pfaffia paniculata \\
Quassia & Quassia amara \\
Quebra-pedra & Phyllanthus niruri \\
St. John's wort & Hypericum perforatum \\
Senna & Cassia senna \\
Stevia & Stevia rebaudiana \\
Sucupira & Bowdichia spp \\
Tonka beans & Dipteryx odorata \\
Urucum & Bixa orellana \\
Uva-ursi & Arctostaphylus uva-ursi \\
Valerian & Valeriana officinallis \\
Yarrow & Achilea millefolium \\
Yellow chinchona & Chinchona calisaya \\
\hline
\end{tabular}

(a) 2 samples; (b) 3 samples; (c) 4 samples.

layer chromatography (TLC), as described by Soares and Rodriguez-Amaya (24). The residue obtained above, which was resuspended in $1.0 \mathrm{~mL}$ of chloroform (MERCK), and mycotoxin standards (SIGMA) were spotted onto TLC plates $(20 \times 20 \mathrm{~cm}$ MERCK aluminium sheets, coated with 0.25 -mm layer thickness of silica gel $\mathrm{G}$ ). The chromatogram was developed at room temperature, in unsaturated chamber containing a solvent system composed of a mixture of toluene, ethyl acetate and formic acid (50:40:10). Visualization was performed under UV light at $365 \mathrm{~nm}$.

The chemical confirmation of mycotoxin identity was performed by adequate techniques. The presence of aflatoxins was confirmed by derivatization with trifluoroacetic acid (23) and by spraying the developed plates with aqueous solution of sulfuric acid $50 \%(5,16,18)$. The presence of ochratoxin was confirmed by two-dimensional chromatography and by the exposure of plates to $\mathrm{NH}_{3}$ vapor (23). The presence of citrinine was confirmed by exposure to $\mathrm{NH}_{3}$ vapor (18).

\section{RESULTS AND DISCUSSION}

The risk of the presence of microorganisms in a pharmaceutical product depends on this finality of the use, its nature and its potential damage that may be caused to the consumers. Considering natural flora, current production conditions and the need to warrant the quality and the safety of these products, monographs of the US Pharmacopoeia (26) for products that contain raw material of natural origin establish a maximum fungal contamination limit of $2 \times 10^{2} \mathrm{CFU} / \mathrm{g}$ of the product.

Table 2 presents the frequency of distribution of the 91 samples according to the fungi counts obtained.
Table 2. Distribution of the herbal drugs samples according to the counts of fungi.

\begin{tabular}{cc}
\hline Enumeration limits (CFU/g) & Number of samples \\
\hline $0 \leq 2 \times 10^{1}$ & $11(12.09 \%)$ \\
$2 \times 10^{1} \leq 2 \times 10^{2}$ & $30(32.97 \%)$ \\
$2 \times 10^{2} \leq 2 \times 10^{3}$ & $27(29.67 \%)$ \\
$2 \times 10^{3} \leq 2 \times 10^{4}$ & $14(15.38 \%)$ \\
$2 \times 10^{4} \leq 2 \times 10^{5}$ & $6(6.59 \%)$ \\
$2 \times 10^{5} \leq 2 \times 10^{6}$ & $3(3.30 \%)$ \\
\hline
\end{tabular}

The results showed that $54.9 \%$ of the samples exceeded the limit determined by the US Pharmacopoeia (26) and these results are in agreement with those of previous studies (1618,21,25). Cymbopogon citratus ( $\left.3.98 \times 10^{5} \mathrm{cfu} / \mathrm{g}\right)$, Hypericum perforatum $\left(3.30 \times 10^{5} \mathrm{cfu} / \mathrm{g}\right)$, Equisetum arvense $\left(2.58 \times 10^{5}\right.$ $\mathrm{cfu} / \mathrm{g})$, Trichilia catigua $\left(6.09 \times 10^{4} \mathrm{cfu} / \mathrm{g}\right)$, Baccharis gaudichaudiana (4.56 x $\left.10^{4} \mathrm{cfu} / \mathrm{g}\right)$, Echinodorus macrophyllus $\left(4.12 \times 10^{4} \mathrm{cfu} / \mathrm{g}\right)$, Phytolacca americana $\left(2.92 \times 10^{4} \mathrm{cfu} / \mathrm{g}\right)$, Achyrocline satureoides $\left(2.85 \times 10^{4} \mathrm{cfu} / \mathrm{g}\right)$ and Phyllanthus niruri $\left(1.95 \times 10^{4} \mathrm{cfu} / \mathrm{g}\right)$ were the most contaminated samples. According to plant part used, the highest counts of fungal isolates were observed in leaves and aerial parts $(50.0 \%)$ followed by flowers (16.0\%), rhizomes and roots (12.0\%), barks $(12.0 \%)$ and seeds $(10.0 \%)$.

Although high fungal loads may be accepted due to the natural origin of those products, they indicate the potential for spoilage and mycotoxigenesis (13).

The predominant mycoflora obtained was distributed in 10 genera (Table 3). The genus Aspergillus was the most dominant genus recovered (179 isolates) followed by Penicillium (44 isolates) and these two genera were found in $90.1 \%$ and $39.6 \%$ of the samples analyzed. All these results are in agreement with that reported by others $(1,2,8-11,13,18-22)$. The presence of a wide range of storage fungi indicates that considerable improvements could be made during post-harvest storage.

Strains of Aspergillus flavus, Aspergillus niger and Penicillium citrinum were the most dominant and frequently isolated $(23.39 \%, 20.97 \%$ and $12.50 \%$, respectively), followed by Aspergillus ochraceus (10.48\%), Penicillium chrysogenum (5.24\%) and Aspergillus parasiticus (4.44\%). These results approximate with previous reports that showed Aspergillus flavus, in particular, was the main contaminant of different herbal and spices samples $(1,2,8-11,13,16-21)$.

Most of the identified moulds have been reported to have ability to produce mycotoxins. The 223 isolates of Aspergillus and Penicillium were evaluated for their ability to produce aflatoxins, ochratoxin A and citrinine. The number of isolates, toxigenic isolates and types of mycotoxins they were able to produce are presented in Fig. 1. Fourty-nine of these isolates 
Table 3. Distribution of the fungi detected in samples of herbal drugs.

\begin{tabular}{lc}
\hline \multicolumn{1}{c}{ Fungi isolated } & Number of isolates \\
\hline Alternaria & $1(0.40 \%)$ \\
Aspergillus flavus & $58(23.39 \%)$ \\
Aspergillus fumigatus & $8(3.23 \%)$ \\
Aspergillus niger & $52(20.97 \%)$ \\
Aspergillus ochraceus & $26(10.48 \%)$ \\
Aspergillus parasiticus & $11(4.43 \%)$ \\
Other Aspergillus spp & $24(9.68 \%)$ \\
Chaetomium & $2(0.81 \%)$ \\
Cladosporium & $4(1.61 \%)$ \\
Mucor & $4(1.61 \%)$ \\
Paellomyces & $1(0.40 \%)$ \\
Penicillium chrysogenum & $13(5.24 \%)$ \\
Penicillium citrinum & $31(12.50 \%)$ \\
Phoma & $2(0.81 \%)$ \\
Rhizopus & $9(3.63 \%)$ \\
Trichoderma & $2(0.81 \%)$ \\
\hline
\end{tabular}

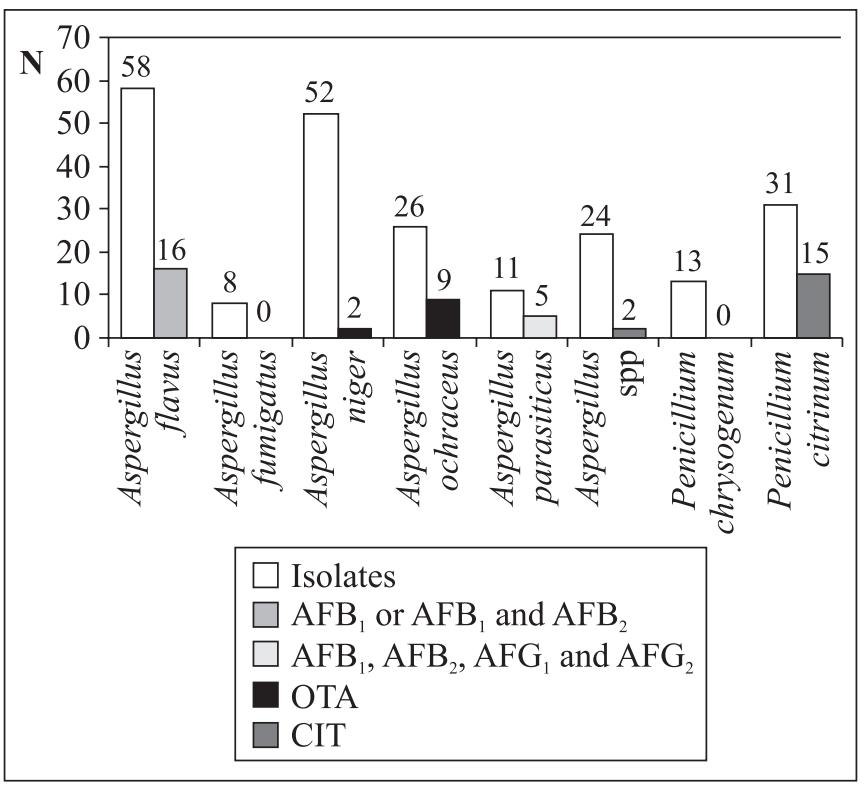

Figure 1. Distribution of toxigenic isolates detected in herbal drugs according to the type of mycotoxins produced.

(21.97\%) were found to produce mycotoxins: $42.9 \%$ were found to be aflatoxigenic strains, $22.4 \%$ ochratoxigenic strains and $34.7 \%$ citrinine-producing strains.

The analysis of Fig. 1 indicated that $27.6 \%$ Aspergillus flavus presented the ability to produce aflatoxin $\mathrm{B}_{1}$ or aflatoxins $\mathrm{B}_{1}$ and $\mathrm{B}_{2} ; 45.5 \%$ Aspergillus parasiticus presented ability to produce aflatoxins $B_{1}, B_{2}, G_{1}$ and $G_{2} ; 34.6 \%$ Aspergillus ochraceus and $3.8 \%$ Aspergillus niger, the ability to produce ochratoxin A; $48.4 \%$ Penicillium citrinum and $8.3 \%$ of other Aspergillus spp, the ability to produce citrinine.

Although this study did not attempt to examine crude herbal drugs for the presence of mycotoxins, the results showed there is a potential risk for mycotoxins contamination, especially during prolonged storage in poorly conditions without temperature and moisture control that usually render medicinal plants more susceptible to moulds growth and mycotoxins production.

\section{CONCLUSION}

In the present study, $54.9 \%$ of the medicinal plants analyzed did not comply with the maximum acceptable limit for fungal contamination. Among fungi isolated, the presence of the genera Aspergillus and Penicillium was greater than other genera. $21.97 \%$ of the Aspergillus and Peniciillium isolates presented the ability to produce mycotoxins, such as aflatoxins, ochratoxin A and citrinine. Although the presence of toxigenic moulds in a product did not imply in mycotoxins detection, their presence represents a potential risk of contamination with mycotoxins. Considering the worldwide increased use of herbal products as alternative medicines and the risk of purchase and use of natural products contaminated with moulds and mycotoxins, it is necessary setting appropriate standards for toxigenic moulds and mycotoxins in crude herbal drugs and medicinal plants in order to reduce the risks for consumers' health.

\section{RESUMO \\ Ocorrência de fungos toxigênicos em drogas vegetais}

$\mathrm{O}$ aumento no consumo de produtos naturais transformou seu uso em um problema de Saúde Pública devido a possibilidade do acesso a produtos sem adequadas condições de uso. A preocupação com a qualidade dos produtos naturais é devida à potencialidade de contaminação por fungos e ao risco da presença de micotoxinas. Noventa e uma amostras de plantas medicinais foram avaliadas quanto à contaminação fungica e ao potencial micotoxigênico de Aspergillus e Penicillium isolados nestas amostras. Os resultados indicaram que a micoflora predominante esteve distribuída entre 10 gêneros. Entretanto, $89,9 \%$ dos isolados corresponderam aos gêneros Aspergillus e Penicillium, extremamente importantes do ponto de vista micotoxicológico. Verificou-se que 21,97\% dos isolados de Aspergillus e Penicillium demonstraram capacidade para produzir aflatoxinas $(42,9 \%)$, ocratoxina A $(22,4 \%)$ e citrinina $(34,7 \%)$. A presença de fungos toxigênicos 
representa risco potencial de contaminação com micotoxinas e considerando o aumento no consumo de produtos de origem vegetal como alternativa terapêutica, é necessário estabelecer padrões para a presença de fungos toxigênicos em drogas vegetais a fim de reduzir os riscos à saúde do consumidor.

Palavras-chave: drogas vegetais, plantas medicinais, fungos toxigênicos, micotoxinas

\section{REFERENCES}

1. Abou-Arab, A.A.K.; Kawther, M.S.; El Tantawy, M.E.; Badeaa, R.I.; Khayria, N. Quantity estimation of some contaminants in commonly used medicinal plants in the Egyptian market. Food Chem., 67, 357-363, 1999.

2. Aziz, N.H.; Youssef, Y.A.; El-Fouly, M.Z.; Moussa, L.A. Contaminantion of some common medicinal plant samples and spices by fungi and their mycotoxins. Bot. Bull. Acad. Sinica., 39(4), 279285,1998

3. Calixto, J.B. Efficacy, safety, quality control, marketing and regulatory guidelines for herbal medicines (phytotherapeutic agents). Braz. J. Med. Biol., 33, 179-189, 2000.

4. Capasso, F. The medicinal plants in our time. Boll. Chim. Farm., 125(9), 322-327, 1986.

5. Chourasia, H.K.; Roy, A.K. Effect of temperature, relative humidity and light on aflatoxin B1 production in Neem and Datura seeds. Int. J. Pharmacognosy, 29(3), 197-202, 1991.

6. Costa, L.L.F.; Scussel, V.M. Toxigenic fungi in beans (Phaseolus vulgaris $\mathrm{L}$.) classes black and color cultivated in the state of Santa Catarina, Brazil. Braz. J. Microbiol., 33, 138-144, 2002.

7. Efuntoye, M.O. Mycotoxins of fungal strains from stored herbal plants and mycotoxin contents of Nigerian crude herbal drugs. Mycopathologia, 147, 43-48, 1999.

8. Elshafie, A.E.; Al-Lawatia, T.; Al-Bahry, S. Fungi associated with black tea and tea quality in the Sultanate of Oman. Mycopathologia, 145, 89-93, 1999.

9. Elshafie, A.E.; Al-Rashdi, T.A.; Al-Bahry, S.N.; Bakheit, C.S. Fungi and aflatoxins associated with spices in the Sultanate of Oman. Mycopathologia, 155, 155-160, 2002.
10. Freire, F.C.O.; Kozakiewicz, Z.; Paterson, R.R.M. Mycoflora and mycotoxins in Brazilian black pepper, white pepper and Brazil nuts. Mycopathologia, 149, 13-19, 2000.

11. Halt, M. Moulds and mycotoxins in herb tea and medicinal plants. Eur. J. Epidemiol., 14, 269-274,1998.

12. Lin, M.T.; Dianese, J.C. A coconut-agar medium for rapid detection of aflatoxin production by Aspergillus spp. Phytopathology, 66(12), 1466-1469, 1976.

13. Mandeel, Q.A. Fungal contamination of some imported spices. Mycopathologia, 159, 291-298, 2005.

14. Pitt, J.I. The genus Penicillium. Sidney, Australia: Academic Press Inc., 1979.

15. Raper, K.B.; Fennel, D.I. The genus Aspergillus. Baltimore: The Williams and Wilkins Company, 1965

16. Reif, K.; Metzger, W. Determination of aflatoxins in medicinal herbs and plant extracts. J. Chromatography A., 692, 131-136, 1995.

17. Rizzo, I.; Vedoya, G.; Maurutto, S.; Haidukowski, M.; Varsavsky, E. Assessment of toxigenic gungi on Argentinean medicinal herbs. Microbiol. Res., 159(2), 113-120, 2004.

18. Roy, A.K.; Chourasia, H.K. Aflatoxin problems in some medicinal plants under storage. Int. J. Crude Drug Res., 27, 156-160, 1989.

19. Roy, A.K.; Chourasia, H.K. Mycoflora, mycotoxin productibility and mycotoxins in traditional herbal drugs from India. J. Gen. Appl. Microbiol., 36, 295-302, 1990.

20. Roy, A.K.; Chourasia, H.K. Mycotoxin incidence in root drugs. Int. J. Crude Drug Res., 28, 157-160, 1990.

21. Roy, A.K.; Kumari, V. Aflatoxin and citrinin in seeds of some medicinal plants under storage. Int. J. Pharmacognosy, 29, 62-65, 1991.

22. Roy, A.K.; Sinha, K.K.; Chourasia, H.K. Aflatoxin contamination of some common drug plants. Appl. Environm. Microbiol., 54, 842843,1988

23. Scott, P.M. Natural Toxins. In: Official Methods of Analysis of AOAC International. $16^{\text {th }}$ ed., volume II, AOAC International, 1995.

24. Soares, L.M.V.; Rodriguez-Amaya, D.B. Survey of aflatoxins, ochratoxins A, zearalenone and sterigmatocystin in some Brazilian foods by using multi-toxin thin layer chromatographic method. $J$. Assoc. Off. Anal. Chem., 72, 22-26, 1989.

25. Tassaneeyakul, W.; Razzazi-Fazeli, E.; Porasuphatana, S.; Bohm, J. Contamination of aflatoxins in herbal medicinal products in Thailand. Mycopathologia, 158, 239-244, 2004.

26. The United States Pharmacopeia. 28. ed. Rockville: United States Pharmacopeial Convention, 2005. 